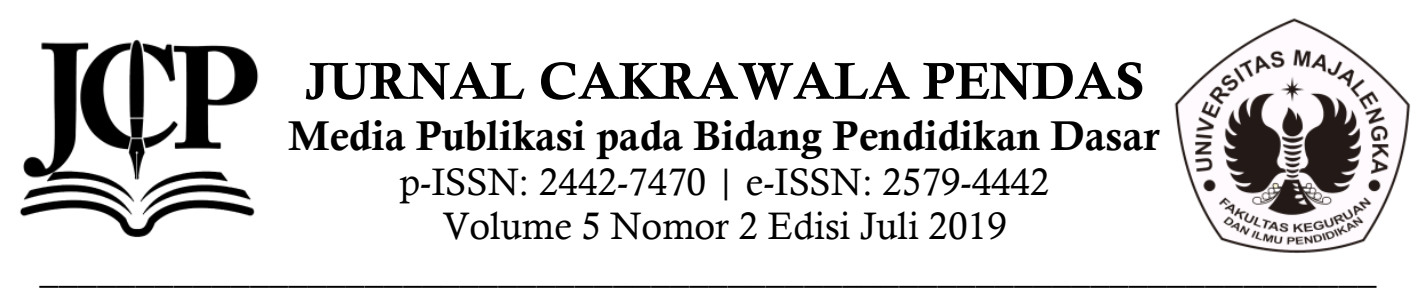

\title{
PENGARUH MODEL LEARNING CYCLE TERHADAP KEMAMPUAN BERPIKIR KRITIS MATEMATIKA SISWA KELAS V SEKOLAH DASAR
}

Een Unaenah $^{1}$, Nurlianti Rahmah ${ }^{2}$

${ }^{1}$ Jurusan Pendidikan Guru Sekolah dasar, Universitas Muhammadiyah Tangerang, Indonesia

${ }^{2}$ Jurusan Pendidikan Guru Sekolah dasar, Universitas Muhammadiyah Tangerang, Indonesia Email: eenuna@gmail.com

\begin{abstract}
Abstrak
Penelitian ini bertujuan untuk mengetahui perbedaan kemampuan berpikir kritis antara siswa yang diberi model pembelajaran Learning Cycle dengan siswa yang diberi model pembelajaran konvensional pada pembelajaran Matematika siswa kelas V SDN Batuceper 1 Tangerang. Penelitian ini menggunakan metode penelitian Quasi Experimental dengan desain penelitian Nonequivalent Control Group Design. Subjek populasi dalam penelitian ini adalah seluruh siswa kelas V SDN Batuceper 1 Tangerang yang berjumlah 60 siswa. Teknik pengumpulan data dengan menggunakan instrument soal tes berbentuk essay yang terdiri dari 10 soal yang valid dan reliabel. Pengujian hipotesis postest dari hasil uji $t$ diperoleh $t_{\text {hitung }} 2,53>t_{\text {tabel }} 2,08$, maka dapat disimpulkan bahwa terdapat perbedaan kemampuan berpikir kritis yang signifikan antara siswa yang menggunakan model pembelajaran Learning Cycle siswa yang menggunakan model pembelajaran konvensional.
\end{abstract}

Kata kunci : Learning Cycle, Kemampuan Berpikir Kritis 


\section{Pendahuluan}

Pendidikan merupakan kebutuhan dasar setiap manusia untuk mempertahankan eksistensi dirinya dalam kehidupan, juga mengantarkan manusia pada kehidupan yang lebih bermartabat dan bermanfaat. Melalui pendidikan akan melahirkan manusia yang cerdas, mempunyai kompetensi dan aktif untuk mengembangkan bakat yang dimilikinya serta menciptakan manusia yang berkualitas dan berkarakter sehingga memiliki pandangan yang luas ke depan untuk mencapai cita-citanya.

Sesuai dengan tujuan pendidikan nasional bahwa pendidikan sekolah dasar tidak hanya membekali para siswa mempunyai kemampuan membaca, menulis, dan menghitung. Melainkan juga untuk mengembangkan keterampilan dan potensi siswa baik mental maupun spiritual.

Upaya yang dilakukan agar tercapainya tujuan pendidikan sesuai yang diharapkan, maka baik siswa maupun guru perlu memiliki sikap, kemampuan, kemauan dan keterampilan yang mendukung proses belajar mengajar. Dengan demikian, siswa dan guru mempunyai keterkaitan yang tidak dapat dipisahkan. Siswa tidak sematamata menerima segala sesuatu yang diberikan oleh guru, tetapi juga mengembangkan potensi yang dimiliki. Guru sebagai pendidik merupakan pihak yang berpengaruh dalam proses pembelajaran diharapkan dapat membawa para siswa kepada tujuan pembelajaran yang akan dicapai dan memfasilitasi siswa dalam mengembangkan potensi dirinya secara optimal.

Pendidikan di sekolah dasar merupakan satuan pendidikan dasar formal bagi anak yang berusia antara 7 sampai 13 tahun yang dikembangkan sesuai dengan satuan pendidikan, potensi atau karakteristik daerah, dan sosial budaya di suatu daerah tertentu yang ditetapkan melalui kurikulum. Penyelenggaraan pendidikan di sekolah dasar yaitu selama 6 (enam) tahun dari kelas 1 (satu) sampai kelas 6 (enam). Pelaksanaan dalam pendidikan sekolah dasar terdapat sejumlah materi atau mata pelajaran yang harus dikuasai oleh siswa. Mata pelajaran tersebut antara lain seperti pendidikan agama (diberikan sesuai dengan agama atau kepercayaan yang dianut siswa, yaitu agama Islam, Kristen, Khatolik, Hindu, dan Budha), pendidikan Kewarganegaraan, Bahasa Indonesia, Ilmu Pengetahuan Alam, Ilmu Pengetahuan Sosial, Matematika, Pendidikan Jasmani dan Olahraga, Seni Budaya dan Kerajinan, dan juga mata pelajaran muatan lokal yang berkembang di daerah tersebut. Dengan mata pelajaran yang harus mampu dikuasai oleh siswa tersebut maka dapat dikatakan bahwa pendidikan di sekolah dasar sebagai pusat pendidikan.

Siswa usia sekolah dasar adalah anak dalam tahapan operasional konkret sesuai dengan teori yang dikemukakan oleh Piaget. Dimana tahapan kognitif siswa baru mampu berpikir sistematis mengenal bendabenda dan peristiwa-peristiwa yang konkret. Matematika merupakan disiplin ilmu yang mempunyai sifat khas. Kekhasan itu berkenaan dengan ide-ide atau konsepkonsep abstrak yang tersusun secara hirarkis hingga tidak mudah dipahami oleh siswa sekolah dasar pada umumnya. Menurut Susanto Ahmad matematika merupakan cara berpikir logis yang dipersentasikan dalam bilangan, ruang, dan bentuk dengan aturan-aturan yang telah ada yang tak lepas dari aktivitas insani tersebut. Dengan demikian dapat dikatakan bahwa matematika sebagai pembelajaran yang mengasah kemampuan berpikir siswa untuk mengahadapi tantangan ke depan dalam kehidupan sehari-hari.

Maka dapat dipahami bahwa tujuan pendidikan matematika yang diajarkan mulai sejak dini adalah sebagai upaya untuk membekali kemampuan berpikir logis, analitis, sistematis, kritis, dan kreatif serta kemampuan bekerja sama sehingga siswa memiliki kompetensi di masa depan. Selain itu, dengan pembelajaran matematika dapat memberikan tekanan penalaran dalam penerapan matematika. Siswa diarahkan untuk memiliki pemikiran yang kritis dalam memahami setiap konsep yang ada. Sedangkan guru sebagai fasilitator bukan hanya bertugas memindahkan suatu konsep yang dimiliki kepada siswa. Melainkan membantu para siswa memahami suatu konsep atau bahkan menemukan konsep-konsep baru. 
Realita di dunia pendidikan saat ini, kemampuan siswa dalam berpikir kritis dan sistematis kurang diasah. Mata pelajaran matematika khususnya, siswa hanya mampu mengahafal konsep suatu rumus, sementara keterampilan siswa dalam berpikir dan memecahkan masalah yang dapat dihubungkan dengan kehidupan sehari-hari kurang terasah. Sehingga ketika berhadapan dengan masalah yang ada di kehidupan sehari-hari berkaitan dengan materi yang telah diajarkan, siswa tidak dapat mengaplikasikannya dengan baik.

Kurang adanya interaksi antara guru dan siswa dalam proses pembelajaran merupakan salah satu faktor yang menyebabkan masalah tersebut terjadi. Kegiatan guru dalam proses pembelajaran hanya menerangkan dan memberikan contoh soal kemudian meminta siswa mengerjakan soal yang terdapat di lembar kerja siswa. Hanya terjadi komunikasi satu arah dalam proses pembelajaran, yang mengakibatkan siswa terlalu terbiasa menerima sesuatu apapun yang diberikan tanpa berusaha berpikir dan mempertanyakan tentang kejelasan sesuatu tersebut. Maka ketika siswa dihadapkan dengan soal pemecahan masalah yang berbeda dengan apa yang sudah dipelajari, siswa akan merasa kebingungan namun malas bertanya. Faktor masalah tersebut adalah model pembelajaran tidak berpusat pada siswa yang diduga berpengaruh terhadap kemampuan berpikir kritis siswa. Dimana siswa menjadi kurang berpartisipsi dalam proses pembelajaran. Juga penggunaan metode pembelajaran konvensional yang sama dan berulang yang mengakibatkan kurangnya motivasi siswa dalam proses pembelajaran.

Selain itu, anggapan negatif siswa terhadap matematika diduga juga berpengaruh terhadap kemampuan berpikir kritis siswa. Dimana siswa sudah terlebih dahulu menyerah terhadap soal-soal yang menurutnya berbeda dengan apa yang telah dijelaskan oleh guru. Apalagi soal-soal yang mengerahkan kemampuan berpikir secara lebih mendalam. Faktor masalah yang lain yaitu minat belajar siswa rendah yang berpengaruh terhadap kemampuan berpikir kritis siswa. Apabila minat belajar siswa rendah maka akan ada keengganan bagi siswa untuk berpikir. Media yang digunakan juga kurang optimal sehingga terdapat pengaruh terhadap kemampuan berpikir kritis siswa. Karena siswa belum sepenuhnya memahami konsep-konsep yang bersifat abstrak maka diperlukan media konkret yang berkaitan dengan kehidupan sehari-hari.

Sesuai dengan faktor-faktor masalah di atas guru dituntut inovatif menggunakan media, strategi, metode dan model pembelajaran dalam menentukan kualitas hasil belajar mengajar. Penggunaan metode dan model yang bervariatif akan lebih diminati siswa, karena dapat menggairahkan proses belajar dan dapat menjembatani gaya belajar siswa dalam menyerap bahan pelajaran. Sebagai fasilitator guru juga dituntut dapat menciptakan lingkungan belajar yang menyenangkan dan membimbing siswa untuk aktif dalam proses pembelajaran. Siswa diajak untuk menemukan dan membangun sendiri pengetahuannya, sehingga proses pembelajaran dapat berjalan dengan baik dan menghasilkan perubahan dalam diri siswa, baik dalam pengetahuan, sikap dan keterampilannya. Sebelum memilih model pembelajaran yang tepat, guru harus memahami materi ajar dan kondisi kelas. Sehingga siswa dapat berpartisipasi dan lebih aktif dalam proses pembelajaran. Seperti yang telah diuraikan bahwa, matematika memerlukan kemampuan berpikir yang mengarah keabstrak, maka diperlukan model pembelajaran yang memberikan kesempatan bagi siswa untuk mengutarakan konsep yang dimiliki.

Model pembelajaran learning cycle merupakan salah satu alternatif penggunaan model pembelajaran yang dapat digunakan dalam mata pelajaran matematika. Ciri khas model pembelajaran learning cycle adalah setiap siswa secara individu belajar materi pembelajaran yang sudah disiapkan guru. Kemudian hasil belajar individual dibawa ke kelompokkelompok untuk didiskusikan oleh anggota kelompok dan semua anggota kelompok bertanggung jawab secara bersama-sama atas keseluruhan jawaban. Sesuai dengan teori kontruktivisme bahwa siswa harus membangun sendiri pengetahuan yang 
telah diterimanya. Sehingga proses pembelajaran diharapkan menjadi lebih bermakna dan menyenangkan serta proses memahami konsep dan kemampuan berfikir kritis siswa menjadi lebih terasah. Siswa juga tidak hanya sebatas mampu menjawab soal-soal, namun mampu menjelaskan konsep dasarnya dan menerapkan dalam kehidupannya.

Richard W. Paul dalam bukunya berjudul Logic as Theory of Validation: An Essay in Philosophical Logic, menyatakan bahwa:

Critical thinking is the intellectually disciplined process of actively and skillfully conceptualizing, applying, analyzing, synthesizing, and/or evaluating information gathered from, or generated by, observation, experience, reflection, reasoning, or communication, as a guide to belief and action.

Berpikir kritis adalah proses disiplin secara intelektual dimana seseorang secara aktif dan terampil memahami, mengaplikasi, menganalisis, mensintesakan, dan mengevaluasi berbagai informasi yang dia kumpulkan atau yang dia ambil dari pengalaman, dari pengamatan (observasi), dari refleksi yang dilakukannya, dari penalaran, atau dari komunikasi yang dilakukan (Sihotang, dkk., 2012, h.5). Dari definisi tersebut dapat dikatakan bahwa berpikir kritis adalah berpikir atas segala sesuatu yang dialami oleh diri sendiri, yang kemudian diproses lebih mendalam lalu disimpulkan.

Model Learning Cycle (Siklus Pembelajaran) adalah suatu model pembelajaran yang berpusat pada siswa (Student Centered). Yang memungkinkan siswa untuk tidak hanya mengamati hubungan, tetapi juga menyimpulkan dan menguji penjelasan konsep-konsep yang dipelajari. Menurut Fajaroh (2007) Learning Cycle adalah suatu model pembelajaran yang berpusat pada siswa (student centered) yang merupakan rangkaian tahap-tahap kegiatan yang diorganisasi sedemikian rupa sehingga siswa dapat menguasai kompetensi yang harus dicapai dalam pembelajaran dengan berperan aktif.

$$
\text { Model pembelajaran ini }
$$
dikembangakan J. Myron Atikin Robert
Karplus dan kelompok SCIS (Science Curriculum Improvement Study), di Universitas California, Bekeley, Amerika Serikat sejak tahun 1970-an. Pada awalnya Learning Cycle dikembangkan ke dalam tiga fase pembelajaran, yaitu fase exploration, fase invention, dan fase discovery, yang kemudian istilahnya diganti menjadi Exploration, Concept introduction, dan Concept Application (E-I-A). Kemudian ketiga fase ini dikembangkan dan dirinci lagi menjadi lima fase, yang dikenal dengan sebutan $5 E$ (Engangement, Exploration, Explanation, Elaboration/Extention, dan Evaluation) (Laelasari, Subroto, \& Ihsan, 2014, h.84).

Secara umum, learning cycle sesuai dengan teori belajar Jean Piaget yang berbasis kontruktivisme. Piaget menyatakan bahwa belajar merupakan pengembangan aspek kognitif yang meliputi struktur, isi, dan fungsi. Menurut Arifin, struktur intelektual adalah organisasi-organisasi mental tingkat tinggi yang dimiliki individu untuk memecahkan masalah-masalah. Isi adalah perilaku khas individu dalam merespon masalah yang dihadapai. Sementara fungsi merupakan proses perkembangan intelektual yang mencangkup adaptasi dan organisasi (Shoimin, 2014, h.58).

Menurut Bybee dengan kesuksesan siklus belajar model $5 \mathrm{E}$ dan intruksional yang meneliti tentang bagaimana orang belajar dari penelitian mendengar dan mengembangkan kurikulum yang menuntut bahwa model 5E dapat diperluas lagi menjadi model 7E (Laelasari, Subroto, dan Ihsan, 2014, h. 85). Dapat dilihat pada gambar 1 berikut:

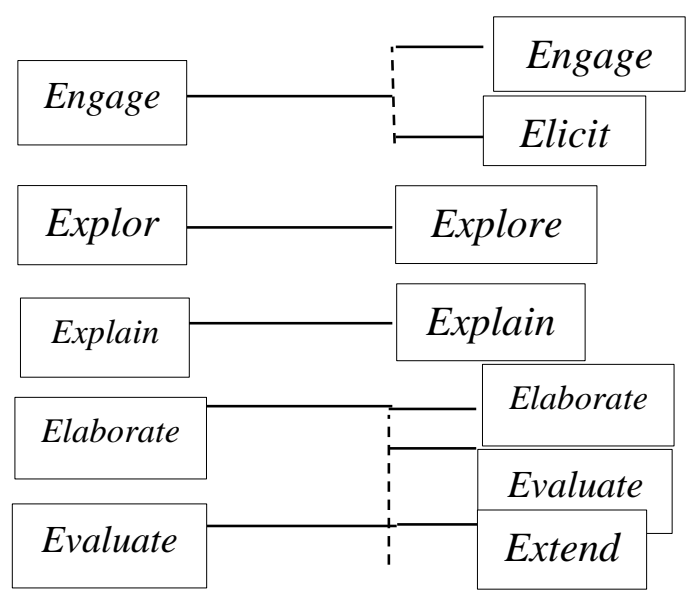


Gambar 1

Diagram Perubahan Tahapan Learning Cycle 5E menjadi 7E (Eisenkraft, 2003)

Menurut Eisenkraft fase-fase model Learning Cycle $7 E$ dapat dijelaskan sebagai berikut:

a. Elicit (Mendatangkan Pengetahuan Awal Siswa)

Merupakan fase untuk mengetahui sampai dimana pengetahuan awal siswa terhadap pelajaran yang akan dipelajari dengan memberikan pertanyaan-pertanyaan yang merangsang pengetahuan awal siswa agar timbul respon dari pemikiran siswa serta menimbulkan kepenasaran tentang jawaban dari pertanyaan-pertanyaan yang diajukan oleh guru. Fase ini dimulai dengan pertanyaan mendasar yang berhubungan dengan pelajaran yang akan dipelajari dengan mengambil contoh yang mudah yang diketahui siswa seperti kejadian sehari-hari yang secara umum memang terjadi.

b. Engage (Ide, Rencana Pembelajaran Dan Pengalaman)

Merupakan fase dimana siswa dan guru akan saling memberikan informasi dan pengalaman tentang pertanyaan-pertanyaan awal tadi, memberitahukan siswa tentang ide dan rencana pembelajaran sekaligus memotivasi siswa agar lebih berminat untuk mempelajari konsep dan memperhatikan guru dalam mengajar. Fase ini dapat dilakukan dengan demonstrasi, diskusi, membaca, atau aktivitas lain yang digunakan untuk membuka pengetahuan siswa dan mengembangkan rasa keingin tahuan siswa.

c. Explore (Menyelidiki)

Merupakan fase yang membawa siswa untuk memperoleh pengetahuan dengan pengalaman langsung yang berhubungan dengan konsep yang akan dipelajari. Siswa dapat mengobservasi, bertanya, dan menyelidiki konsep dari bahan-bahan pembelajaran yang telah disediakan sebelumnya.

d. Explain (Menjelaskan)

Merupakan fase yang didalamnya berisi ajakan terhadap siswa untuk menjelaskan konsep-konsep dan definisi-definisi awal yang mereka dapatkan ketika fase eksplorasi. Kemudian dari definisi dan konsep yang telah ada didiskusikan sehingga pada akhirnya menuju konsep dan definisi yang lebih formal.

e. Elaborate (Menerapkan)

Merupakan fase yang bertujuan untuk membawa siswa menjelaskan definisidefinisi, konsep-konsep, dan keterampilanketerampilan pada permasalahanpermasalahan yang berkaitan dengan contoh dari pelajaran yang dipelajari.

f. Evaluate (Menilai)

Merupakan fase evaluasi dari hasil pembelajaran yang telah dilakukan pada fase ini dapat digunakan berbagai strategi penilaian formal dan informal. Guru diharapkan secara terus menerus dapat mengobservasi dan memperhatikan siswa terhadap kemampuan dan keterampilannya untuk menilai tingkat pengetahuan dan atau kemampuannya, kemudian melihat perubahan pemikiran siswa terhadap pemikiran awalnya.

g. Extend (Memperluas)

Merupakan fase yang bertujuan untuk berpikir, mencari menemukan dan menjelaskan contoh penerapan konsep yang telah dipelajari bahkan kegiatan ini dapat merangsang siswa untuk mencari hubungan konsep yang mereka pelajari dengan konsep lain yang sudah atau belum mereka pelajari.

Fase-fase pembelajaran yang telah dipaparkan di atas adalah hal-hal yang harus dilakukan guru dan siswa untuk menerapkan Learning Cycle 7E pada pembelajaran di kelas. Guru dan siswa mempunyai peran masing-masing dalam setiap kegiatan pembelajaran yang dilakukan dengan menggunakan tahapan dari siklus belajar.

\section{Metode Penelitian}

Metode penelitian yang digunakan peneliti dalam penelitian ini adalah metode eksperimen semu (Quasi Eksperimen). Metode penelitian ini bertujuan untuk memprediksi keadaan yang dapat dicapai melalui eksperimen yang sebenarnya, tetapi tidak ada pengontrolan dan manipulasi terhadap seluruh variable yang relevan.

Penelitian ini menggunakan desain berbentuk Nonequivalent Control Group Design dengan menggunakan dua kelompok yang terdiri dari kelompok eksperimen dan 
kelompok kontrol. Perlakuan (eksperimen) yang diberikan pada penelitian ini adalah model learning cycle, sedangkan aspek yang diukurnya adalah kemampuan berpikir kritis matematika siswa. Oleh karena itu, yang menjadi variabel bebas adalah model learning cycle dan variabel terikat adalah kemampuan berpikir kritis matematika. Dengan demikian desain penelitian ini dapat dilihat sebagai berikut :

\begin{tabular}{cccc}
\hline Kelompok & Pretes & Perlakuan & Postes \\
\hline Eksperimen & $\mathrm{O}_{1}$ & $\mathrm{X}$ & $\mathrm{O}_{2}$ \\
\hline Kontrol & $\mathrm{O}_{3}$ & - & $\mathrm{O}_{4}$ \\
\hline
\end{tabular}

Keterangan:

$\mathrm{O}_{1}=$ Data hasil pretes kelas eksperimen

$\mathrm{O}_{2}=$ Data hasil postes kelas eksperimen

$\mathrm{O}_{3}=$ Data hasil pretes kelas kontrol

$\mathrm{O}_{4} \quad=$ Data hasil postes kelas kontrol

$\mathrm{X}=$ Perlakuan pada kelas eksperimen yang diberi model learning cycle

Populasi dalam penelitian ini adalah siswa kelas V A dan siswa kelas V B di SDN Batuceper 1 Tangerang yang berjumlah 60 siswa dengan perincian sebagai berikut :

Sampel yang digunakan dalam penelitian ini adalah sampel jenuh. Dimana seluruh anggota populasi digunakan sebagai sampel. Sampel yang akan digunakan dalam penelitian ini adalah seluruh kelas $\mathrm{V}$ A yang terdiri dari 30 orang siswa sebagai kelas eksperimen dan seluruh kelas V B yang terdiri dari 30 orang siswa sebagai kelas kontrol.

Teknik pengumpulan yang akan digunakan pada penelitian sebagai berikut:

a. Observasi

Teknik pengumpulan data dalam penelitian ini salah satunya adalah observasi dengan jenis observasi terstruktur. Terdapat beberapa hal yang akan diobservasi baik di kelas eksperimen maupun di kelas kontrol, yaitu; a) persiapan mengajar, b) kondisi kelas, c) aktivitas guru, d) aktivitas respon siswa, dan e) pengelolaan kelas

b. Tes

Pengumpulan data melalui teknik tes ini, mencangkup pada indikator kemampuan berpikir kritis siswa pada mata pelajaran, a) memberikan penjelaskan sederhana, b) membangun keterampilan dasar, c) menyimpulkan, d) memberikan penjelaskan lanjut, dan e) mengatur strategi dan taktik. c. Dokumentasi

Pengumpulan data menggunakan teknik dokumentasi ini, berupa analisis dokumendokumen yang diperlukan dalam proses penelitian, yaitu; a) hasil belajar siswa baik kelas eksperimen maupun kelas kontrol, b) kurikulum yang digunakan sekolah, c) silabus yang digunakan di sekolah, dan d) rpp mata pelajaran matematika yang digunakan kelas eksperimen dan kelas kontrol.

Teknik analisis data yang akan digunakan pada penelitian sebagai berikut:

a. Analisis Statistik Deskriptif

Arifin (2012), statistik deskriptif atau statistik deduktif (descriptive or deducative statistics) adalah statistik yang mempunyai tugas untuk mengumpulkan, mengolah dan menganalisis data, kemudian menyajikannya dengan baik (h. 251) Penyajian data dalam statistik deskripif berupa tabel distribusi frekuensi, histogram, poligon dan diagram ogive, penjelasan kelompok melalui modus, median, mean, dan penyebaran data dengan varians.

b. Analisis Statistik inferensial

Arifin (2012) statistik inferensial atau statistik induktif (inductive statistics or statistical inference), yaitu statistik yang mempunyai tugas mengambil kesimpulan dan membuat keputusan yang baik dan rasional, di samping mengumpulkan data, menyajikan, menganalisa dan menginterpretasikan-nya. Adapun untuk menganalisa statistik inferensial menggunakan uji normalitas dan uji homogenitas, kemudian dilanjutkan dengan uji hipotesis.

\section{Hasil dan Pembahasan}

Berdasarkan hasil analisis pretes yang menggunakan uji the pooled varians model $t$ test diperoleh $t_{\text {hitung }}=1,94$ dan $t_{\text {tabel }}=2,08$ pada taraf signifikan $\alpha=0,05$. Dari hasil perhitungan tersebut diperoleh harga $t_{\text {hitung }}$ $(1,94)<t_{\text {tabel }}(2,08)$ maka dapat disimpulkan $\mathrm{H}_{\mathrm{o}}$ diterima artinya tidak terdapat pengaruh yang signifikan terhadap kemampuan berpikir kritis siswa yang diberi 
pembelajaran menggunakan media konvensional dengan pembelajaran yang menggunakan model learning cycle.

Berdasarkan hasil analisis postes yang menggunakan uji $\mathrm{t}$ the pooled varians model $t$ test diperoleh $\mathrm{t}_{\text {hitung }}=2,53$ dan $\mathrm{t}_{\text {tabel }}=2,08$ pada taraf signifikan $\alpha=0,05$. Dari hasil perhitungan tersebut diperoleh harga $t_{\text {hitung }}$ $(2,53)>t_{\text {tabel }}(2,08)$ maka dapat disimpulkan $\mathrm{H}_{1}$ diterima artinya terdapat terdapat pengaruh yang signifikan terhadap kemampuan berpikir kritis yang diberi model learning cycle dengan diberi model konvensional.

Hasil pengujian hipotesis menggunakan uji-t dapat dilihat pada tabel berikut:

Tabel 1

Hasil Uji-t Data Pretest dan Postest Kelas Eksperimen dan Kelas Kontrol

\begin{tabular}{ccc} 
Data & Nilai $t_{\text {hitung }}$ & Nilai $_{\text {tabel }}$ \\
\hline Pretes & 1,94 & 2,08 \\
\hline Postest & 2,53 & 2,08 \\
\hline
\end{tabular}

Pada hipotesis yang pertama, dapat dilihat bahwa tidak terdapat perbedaan signifikan kemampuan berpikir kritis antara siswa yang diberi pembelajaran menggunakan model konvensional dengan siswa yang diberi pembelajaran menggunakan model learning cycle.

Sedangkan pada hipotesis yang kedua, terdapat perbedaan signifikan kemampuan berpikir kritis antara siswa yang diberi pembelajaran menggunakan model konvensional dengan siswa yang diberi pembelajaran menggunakan model learning cycle.

\section{Kesimpulan}

Kesimpulan hasil penelitian yang telah dilakukan di SDN Batuceper 1 Tangerang, sebagai berikut:

a. Berdasarkan hasil uji-t data pretest terdapat perbedaan rata-rata kemampuan berpikir kritis antara siswa yang pembelajarannya dengan menggunakan learning cycle $7 \mathrm{E}$ dengan pembelajaran secara konvensional.

b. Berdasarkan hasil analisis terdapat peningkatan kemampuan berpikir kritis yang signifikan pada siswa yang pembelajarannya

menggunakan learning cycle 7E.

\section{Daftar Pustaka}

Arifin, Z. (2012). Penelitian PendidikanMetode dan Paradigma Baru. Bandung: PT. Remaja Rosdkarya.

Arikunto, S. (2014). Prosedur PenelitianSuatu Pendekatan Praktik. Jakarta: Rineka Cipta.

Eisenkraft, A. (2003, September). Expanding The 5E Model. The Science Teacher, 56-59.

Fisher, A. (2014). Berpikir Kritis-Sebuah Pengantar. Jakarta: Erlangga.

Hendriana, H., Rohaeti, E. E., \& Sumarmo, U. (2017). Hard Skills dan Soft Skill Matematika Siswa. Bandung: PT. Refika Aditama.

Heruman. (2017). Model Pembelajaran Matematika di Sekolah Dasar. Bandung: PT. Remaja Rosdakarya.

Huda, M. (20114). Model-Model Pengajaran dan Pembelajaran, Isu-Isu Metodis dan Paradigmatis. Yogyakarta: Pustaka Pelajar.

Karso, Suryadi, G., Muhsetyo, G., Chadra, T. D., Widagdo, D., \& Priatna, N. (2014). Pendidikan Matematika I. Tangerang Sean: Unlativersitas Terbuka.

Laelasari, Subroto, T., \& K, N. I. (2014). Penerapan Model Pembelajaran Learning Cycle 7E Dalam Kemampuan Berprestasi Matematis Mahasiswa. Jurnal Euclid, I(2), 8292.

Purwanto, N. (2013). Psikologi Pendidikan. Bandung: PT. Remaja Rosdakarya.

Riadi, E. (2015). Metode Statistika Parametrik \& Nonparametrik-Untuk Penelitian Ilmu-ilmu Sosial dan Pendidikan. Pustaka Mandiri. 
Shoimin, A. (2014). 67 Model Pembelajaran Inovatif dalm Kurikulum 2013. Yogyakarta: AR-Ruzz Media.

Sihotang, K., K, F. R., Molan, B., Ujan, A. A., \& Ristyantoro, R. (2012). Critical Thinking-Membangun Pemikiran Logis. Jakarta: PT. Pustaka Sinar Harapan.

Sugiyono. (2016). Metode Penelitian Kuantitatif, Kualitatif, dan $R \& D$. Bandung: Alfabeta.

Susanto, A. (2016). Teori Belajar dan Pembelajaran di SD. Jakarta: Prenada Media Group.

Syah, M. (2014). Psikologi Pendidikan dengan Pendekatan Baru. Bandung: PT. Remaja Rosdakarya.

W, N. (2008). Ensiklopedia MatematikaPecahan. Sidoarjo: Citra Adi Bangsa.

Yunarti, T. (2016). Metode Socrates dalam Pembelajaran Berpikir Kritis Aplikasi dalam Matematika. Yogyakarta: Media Akademi. 